\title{
Auscultation of a Dam for Mining Restoration in Quebec, Canada
}

\author{
Coulibaly Yaya, Li Zhen Cheng*, Tikou Belem and Sylvain Lortie
}

University of Québec in Abitibi-Témiscamingue, Canada

\begin{abstract}
The tailing management is a long term concern for environment and social security. Following the discovery of a new gold mineralization, a mining company aims at reusing one of tailings storage facility at the mining site. However, there is a small treated water reservoir (polishing pond) downstream of the Northwest dam. It is therefore important to know the present state of the Northwest dam's internal structure. Geophysical methods of electrical resistivity and georadar were used for the auscultation of the Northwest dam. Numerical models were subsequently used to assess the geotechnical behavior of the dam in different deposition situations by simulating the restoration.

The image processing results of georadar data show a layered structure near the surface. Changes in electrical resistivity offer deeper information than georadar. The lateral variability of the electrical resistivity corresponds to heterogeneity within each layer. As we cannot collect samples for the characterization of materials, the geophysical interpretation results help to estimate the compositional structure of the dam; ultimately it helps in numerical modeling on the safety factor estimation.
\end{abstract}

Keywords: Dam; Embankment; Electrical resistivity; Factor of safety; Georadar; Internal structure; Tailings pond

\section{Introduction}

The Abitibi greenstone belt of Canada is a world well-known region rich in mineral resources. By-products from exploitation of those natural resources could cause acid mine drainage (AMD) due to the interaction between water discharges, atmospheric oxygen and sulphide minerals. In some cases, metals as nickel (Ni), zinc ( $\mathrm{Zn})$, cobalt (Co), copper $(\mathrm{Cu})$ and metalloids as arsenic (As) and antimony (Sb) may generate contaminated neutral mine drainage (DNC). The AMD and the DNC are considered the most important environmental issues, as they may affect the population's quality of life by contamination of surface water and groundwater. To minimize environmental risks, mining companies have developed some waste management strategies: either 1) make cemented paste for backfilling underground; or 2) by stacking them to the surface with impermeable cover; or 3) dropping in the lake bottom around the operation site (tailings). Tailings dams play an important role to separating contaminated and uncontaminated areas. The stability of dams is thus a key element to be monitoring, especially in intensive mining activities region as the Abitibi greenstone belt. Tailings are a mixture of water and fine material from rocks after concentrated minerals being removed and they are piped into a storage facility (e.g. lakes) belted by dams. However, dams can sometimes yield to different types of hazards and dumping of pulp residues and cause extensive damage and major environmental impacts. Figure 1 shows the breakdown of the dam around tailings from Mount Polley in Canada with over 24 million $\mathrm{m}^{3}$ spilled [1]. Damage with the death of 19 people is also recorded due to the bursting of tailings dam in Mariana, Brazil in 2015 [2]. Figure 2 shows the socioeconomic impact of disruptions in the world with the loss of life and on the environment that was increased from 2000 to $2010.76 \%$ of incidents worldwide were related to the upstream construction method [3]. 51\% of incidents (breakdowns and accidents) identified by $\operatorname{ICOLD}(1996,2001)$ are due to slope instability of the dam following excessive stress in the foundation soil, the embankment of the dam, inadequate control of water pressure [4].

The causes of breaking dams are multiple. Apart from construction problems, poor maintenance or unusual weather as cited by Azam and $\mathrm{Li}$ [5], other vulnerability may also be the cause such as the excess pore pressures accumulation due to rapid rising of the dam. The pore pressure (especially in muddy areas) will reduce the effective stresses and resistance to shear residues [6,7]. The static and seismic liquefaction are also considered a common cause of levees broke particularly those enhanced by the upstream method [8,9]. As the break is a physical process (mechanical, hydraulic), in general, the breakdown for embankments is made according to four classical mechanisms [10-12]: external erosion, internal erosion, external instability and liquefaction (Figure 3).

Runoff of rain water can be the cause of the external erosion. The settlements on the crest cause cracks that promote water infiltration into the dam and this could cause internal erosion or slippage in an area of weakness.

\section{Issue of study}

A Canadian mining company discovered a new deposit of gold mineralization around an old mining site in the Abitibi greenstone belt of Québec, Canada. The restoration of a tailings lake to store waste rocks is then planned. According to information gathered at the site, a collapsing zone on the Northwest dam was observed in spring 2004

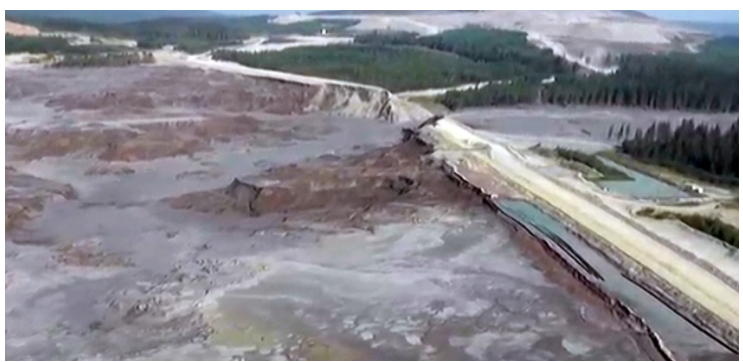

Figure 1: Illustration of embankment failure-cases of the tailings from Mount Polley (Cariboo Regional District, Canada, 2014) [1].

*Corresponding author: LiZhen Cheng, University of Québec in AbitibiTémiscamingue, Canada, Tel: +18197620971; E-mail: LiZhen.Cheng@uqat.ca

Received October 20, 2016; Accepted December 05, 2016; Published December 08, 2016

Citation: Yaya C, Cheng LZ, Belem T, Lortie S (2016) Auscultation of a Dam for Mining Restoration in Quebec, Canada. J Civil Environ Eng 6: 259. doi: 10.4172/2165-784X.1000259

Copyright: ( 2016 Yaya C, et al. This is an open-access article distributed under the terms of the Creative Commons Attribution License, which permits unrestricted use, distribution, and reproduction in any medium, provided the original author and source are credited. 


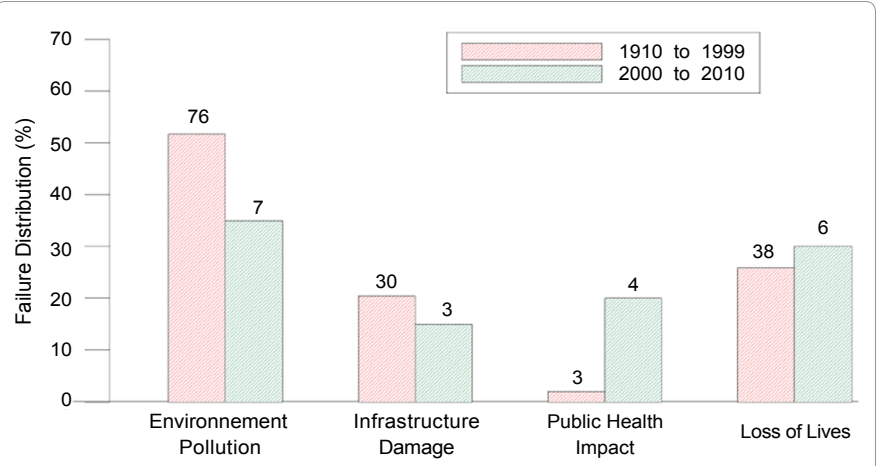

Socio-economic Impact

Figure 2: Illustration of the socio-economic impact breaks the dikes of mining waste in the world from 1910 to 2010 [5]

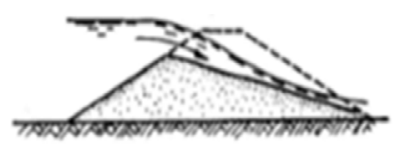

External erosion

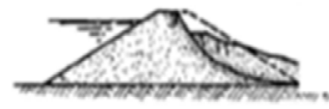

External instability

Figure 3: Illustration breaks for embankments [11,12]

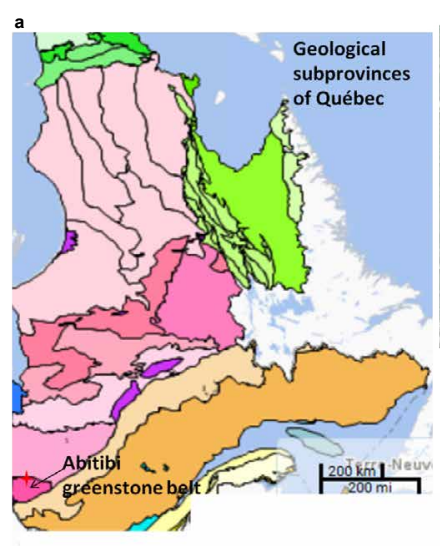

+ Study mine site

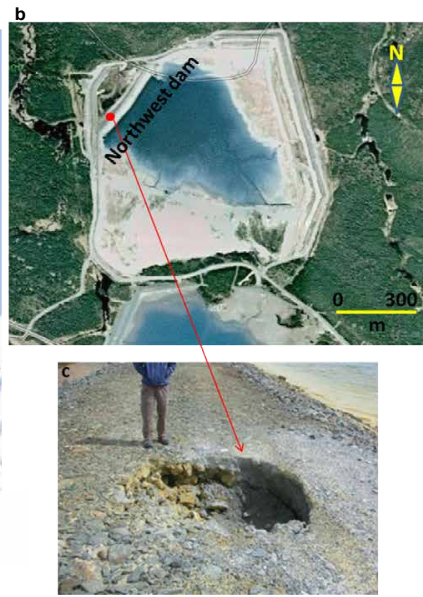

Figure 4: Location of the Northwest dam: a) its location in Québec province; b) the study mine site; c) subsidence observed on the Northwest dam.

(Figure 4). Following this incident, the dam was repaired by cement grout injection. The objective of this study is to investigate the internal structure of the dam with two geophysical techniques (resistivity and ground penetrating radar), in order to evaluate its present status.

\section{Internal Structure of the Dam from Geophysical Observation}

\section{Georadar}

The principle of the GPR (ground penetrating radar) method is: electro magnetic waves at relative high frequency ( $40 \mathrm{MHz}$ to 1500 $\mathrm{MHz}$ ) emitted by a transmitter antenna propagate in the soil, and then reflected while they encounter an interface between materials having different dielectric permittivity. The reflected waves are recorded by another antenna in term of time of arrival and amplitude. In assessing changes in travel time two-way (between the emitter and reflector to the receiver) and the magnitude of the reflection (absolute magnitude) along a profile, the characteristics of the reflector can be identified (equations below for non-magnetic materials). The speed of the wave prop a g a tion mainly depends on electromagnetic properties of the material, and these are governed by the water content [13-16].

$$
D=\frac{t}{2} V \quad V=\frac{c}{\sqrt{\epsilon_{\tau}}}
$$

$c$ is the wave speed in free space $(0.3 \mathrm{~m} / \mathrm{ns}), \mathrm{V}$ is the wave speed of material, $\varepsilon_{r}$ is the relative dielectric permittivity, and $\mathrm{D}$ is estimated depth of the interface where there is a contrast of the dielectric permittivity.

The GPR method is widely used in civil engineering to detect c r a c ks between concrete and steel [17-29]; in hydrogeology and sedimentology [13,30-32]; in archelogy [33,34]; in agriculture for soil types [35]. Despite of the small depth of investigation of GPR, this nondestructive technique has become more popular in recent years for the evaluation of near surface structures through its simplicity and speed of implementation. In general, the frequency assigned to the antennas affects the depth of investigation and resolution of the radar image. The higher the frequency, the depth of the penetration is smaller but the resolution is higher [14]. The depth of penetration also varies depending on the water content $[14,16,36]$. Neal [13] did an excellent review on those complexities in sedimentology. The efficiency of the GPR method to distinguishing geological units depends on the contrast in physical properties such as difference in relative dielectric permittivity and in conductivity, also depends on difference in reflection patterns. Below, Table 1 cites those parameters of several soils and rocks commonly seen in dam environment.

Field work and data processing: Two georadar systems: RIS MF Hi-Mod (IDS) and PulseEKKO (Sensors and Software) were used to collect data in present study. The RIS MF Hi-Mod uses two blinded antennas of $200 \mathrm{MHz}$ and $600 \mathrm{MHz}$ frequencies. The PulseEKKO has three antennas of $50 \mathrm{MHz}, 100 \mathrm{MHz}$ and $200 \mathrm{MHz}$ individually. Figure 5 illustrates the weather condition when those surveys conducted. The GPR data were collected along 24 profiles, but only PulseEKKO data were interpreted for the subsurface structure of the dam because GPS data weren't successfully recorded by RIS HI-Mod. As to PulseEKKO measurements Differential GPS was used for localizing georadar trace location, the base station of GPS is near the northeast end of the dam.

Using REFLEXW, the data processing flow is as follow:

- Since two GPR surveys were conducted in winter time (March 7 and March 17, 2014), we did the time-zero drift correction.

- Elimination of the low frequency noise due to near-surface reflection using the 1D filter function-Subtract mean (Dewow).

- Apply 2D filter-"Background removal" in order to highlight high-frequency signals looking for diffraction hyperboles that could be generated by cavities.

- AGC-Gain or energy decay to enhance low amplitude signals.

- Apply the air velocity $(0.3 \mathrm{~m} / \mathrm{ns})$ to remove surface reflectors' diffraction effect and then use Time-cut to visualize the processing result for the first $10 \mathrm{~m}$ of the depth. 
Citation: Yaya C, Cheng LZ, Belem T, Lortie S (2016) Auscultation of a Dam for Mining Restoration in Quebec, Canada. J Civil Environ Eng 6: 259. doi: 10.4172/2165-784X.1000259

Page 3 of 8

\begin{tabular}{|c|c|c|c|}
\hline Materials & $\begin{array}{c}\text { Dielectric } \\
\text { permittivity } \boldsymbol{\varepsilon}_{\mathbf{r}}\end{array}$ & $\begin{array}{c}\text { Conductivity } \boldsymbol{\sigma} \\
\mathbf{( S / m )}\end{array}$ & Velocity $\mathbf{V}(\mathbf{m} / \mathbf{n s )}$ \\
\hline Air & 1 & 0 & 0.3 \\
\hline Water & 80 & 0.5 & 0.033 \\
\hline Sea water & 80 & 0.003 & 0.01 \\
\hline Dry sand & $3-5$ & 0.01 & 0.15 \\
\hline Wet sand & $20-30$ & $0.1-1$ & 0.06 \\
\hline Limestone & $4-8$ & $0.5-2$ & 0.12 \\
\hline Schist & $5-15$ & $1-100$ & 0.09 \\
\hline Limon (Silt) & $5-30$ & $1-100$ & 0.07 \\
\hline Clay & $5-40$ & $2-1000$ & 0.06 \\
\hline Granite & $4-6$ & $0.01-1$ & 0.13 \\
\hline Ice & $3-4$ & 0.01 & 0.16 \\
\hline Frozen ground & $3-6$ & - & - \\
\hline concrete & $4-10$ & - & - \\
\hline Metal & $1-2$ & - & - \\
\hline
\end{tabular}

Table 1: Dielectric permittivity $\left(\varepsilon_{r}\right)$, conductivity $(\sigma)$ and the velocity $(V)$ of materials $[14,16]$.

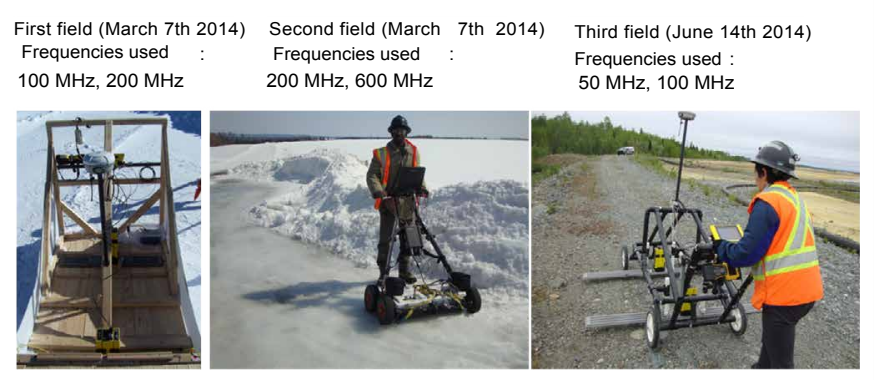

Figure 5: Two ground penetrating radar measurement systems used in this study.

Interpretation: The Northwest dam is oriented along the direction NE-SW (Figure 6). Three GPR profiles have been chosen to present reflection images for the northwest border (Line 11), the central (Line 9 ) and the southeast edge (West 04-69) of the dam. A consistent subparallel reflection pattern through those GPR images demonstrates a shallow layered subsurface structure. Obviously, the first parallel $r$ eflectors on the top of GPR image are generated by airwave and ground wave including thin snow layer reflection. The reflector located at $2 \mathrm{~m}$ to $3 \mathrm{~m}$ of depth (indicated by red arrow) is clearly seen on the profile (Line 11) at the northwest border of the dam, but it is becoming blurred towards the southeast edge of the dam. It seems there is another reflector deeper than $4 \mathrm{~m}$ (indicated by yellow arrows) on line 11, but difficult to see from other two profiles.

B orehole logs from geotechnical drilling F-95-1 are available f or justifying GPR data interpretation. According to the borehole o bservation, the dam is composed of backfill rocks about $5 \mathrm{~m}$ in thickness on the top, and they overly on tailings. Figure 6 shows that the GPR method has very limited depth of penetration, if the reflector indicated by yellow arrows on line 11 corresponds to the interface between the rockfill layer and tailings, the reflection at $2 \mathrm{~m}$ to $3 \mathrm{~m}$ depth may be due to the water table. If it is true, increasing the water content in the lower part of rockfill layer made GPR signal attenuate. For deep structure features, the electric resistivity method may help to go further.

There is a difference in reflection pattern between June (line 09 and line 11) and March (line West04-69) surveys. This could be explained by a high water content of the dam due to the snow melt in June.

\section{Electric resistivity}

The electric resistivity of water is lower than that of rock, variations in the apparent resistivity measured by the electrical method are often correlated with the change in lithology also with the degree of water saturation in rocks (e.g. porous or fractured zones). This technique is widely used to detect voids [37-41], underground water [42-44], fractural zone recognition [45-57], and mineral exploration [58,59]. The difference in resistivity between the target and its surrounding materials is a key factor to ensure this technique is viable. The resistivity of materials used in the construction of dams varies over a range of more than 5 orders of magnitude (Figure 7). This is a major asset for the characterization of materials by the electrical method [60]. Although, the electrical resistivity can be influenced by the porosity and the degree of water saturation of the medium, the clay content, the type of clay, the medium temperature, dry density, pressure and content ions dissolved in the pore water [43,56,61-64], however each substance has a limited range of variation of the resistivity as Figure 8 shows. This is reason why it is possible to estimate the thickness of the materials based on the distribution of the apparent resistivity. Anyhow, the importance of validating the resistivity data interpretation by geotechnical drilling must be considered.

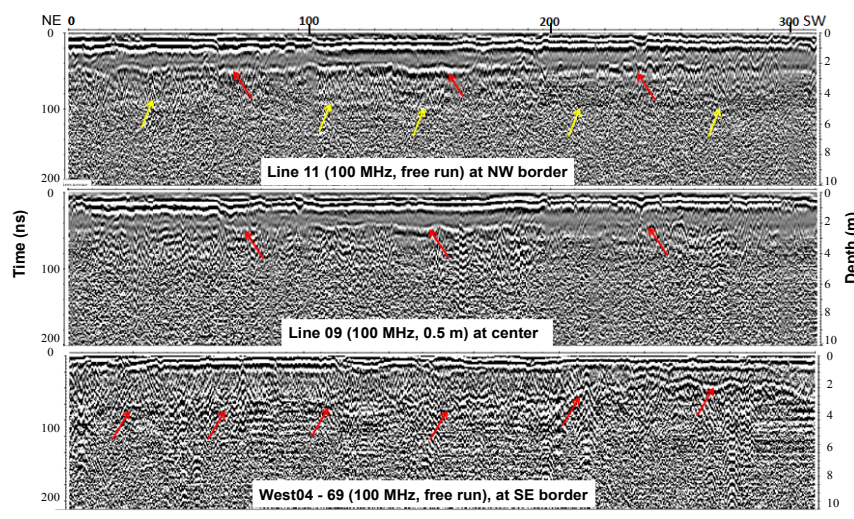

Figure 6: Georadar images.

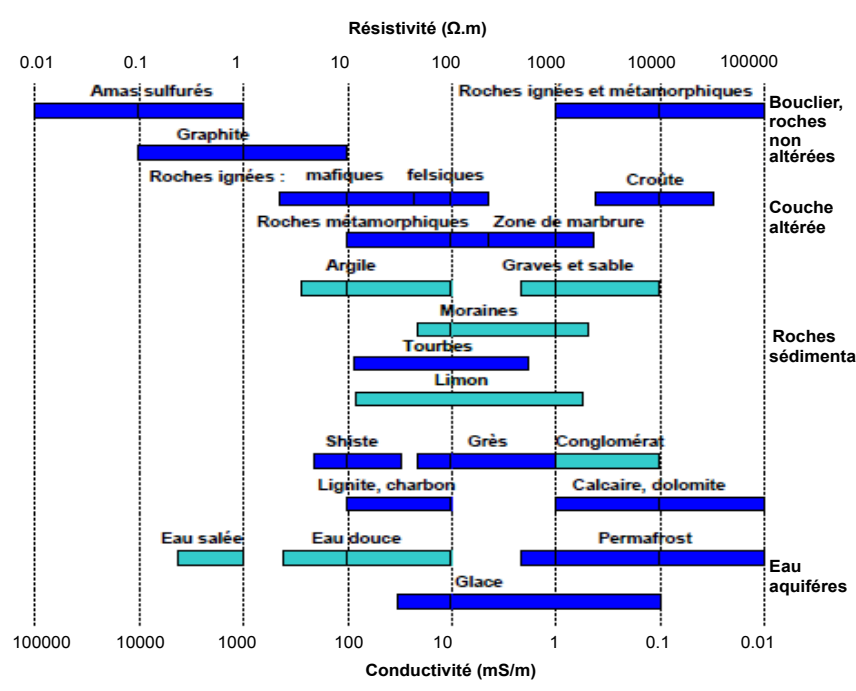

Figure 7: Classification of the resistivity of various soils, rocks and fluids. The light blue color shows the materials commonly used in the composition of the dams $[53,67]$. 


\section{Electrical measurement July 14 and 17 th}

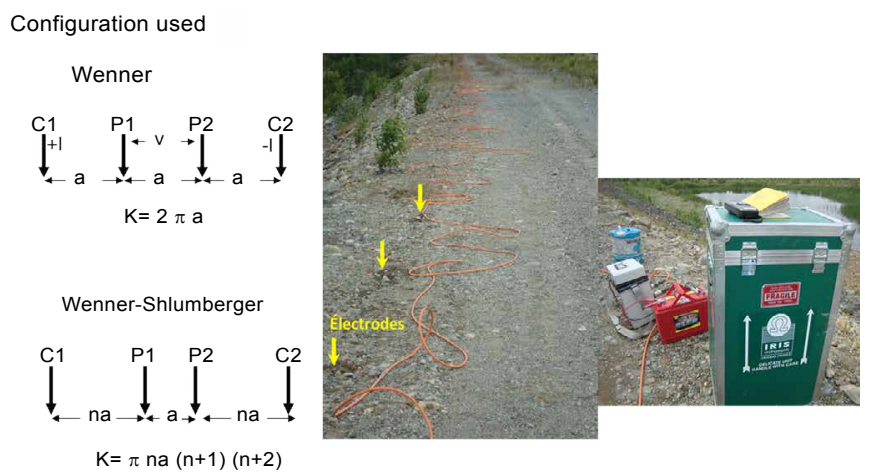

Figure 8: Electrical measurement system used in this study.

Field work and data interpretation: A maximum of seventy-two electrodes of the electrical imaging system 'Syscal R1 Plus Switch 72' (IRIS instrument) was used to auscultate the dam (Figure 9). The $14^{\text {th }}$ of July 2015, the first pseudo-section was performed at the middle of the dam using both the Wenner-Schlumberger and Wenner configurations. The spacing between 72 electrodes is $5 \mathrm{~m}$. The second pseudo-section is on the shelf between a tailings lake (Figure 10) and the Northwest dam, with 54 electrodes and the Wenner-Schlumberger and Wenner configurations, a spacing of $5 \mathrm{~m}$ between electrodes.

The survey of July 17 made three pseudo sections using 72 electrodes; one is at a spacing of $5 \mathrm{~m}$, and another at both spacing of $5 \mathrm{~m}$ and $2.5 \mathrm{~m}$, with the $\mathrm{W}$ enner-Schlumberger and Wenner configurations. The pseudo-section with $5 \mathrm{~m}$ spacing is superimposed on that of July 14. They show a consistent result. Since the surveys of July 14 involve the dam also the tailings, we show those results in the interpretation section.

The resistivity data are then processed by the RES2DINV inversion software (GEOTOMO Software). It estimates apparent resistivity values for each rectangular block of the subsurface by fitting the observation based on the least-square principal. The software determines the error criterion, the inverted resistivity model is then modified to reduce the degree of error between the apparent resistivity measured and calculated. The inversion operation is repeated iteratively until the error reaches to tolerant value [65]. As a layered structure was preliminary interpreted from georadar survey on the dam, the default smoothnessconstrained inversion method is used for the electric resistivity data inversion.

By comparing the inversion result of the pseudo-section in the middle of the dam (Figure 11) with that on the shelf, they show consistent structure with the observation in a geotechnical drilling F-95-1 (Golder Associates in 1996). According to geotechnical logs, from surface to the end of drilling the dam consists of rockfill, tailings slits, the silty clays, the silt and moraine layer. An outcrop was observed at the North-east end of the dam. This outcrop corresponds to schistose sandstone; its resistivity value was estimated between $100 \Omega \bullet \mathrm{m}$ to $1000 \Omega \bullet \mathrm{m}$ by Savoie et al. Our inversion results show that there is a resistivity contrast between different materials; however, it is difficult to distinguish the tailings silts and silty clays from the resistivity. With the help of drilling data, we interpret the distribution of the electrical resistivity in term of changes in materials as cited in Table 2.

Taking into account the variation of water content which affects the electrical resistivity it is sometimes difficult to interpret lithologic boundaries according to the $2 \mathrm{D}$ model of the resistivity inversion. A greater electrical conductivity could be due to high water content as

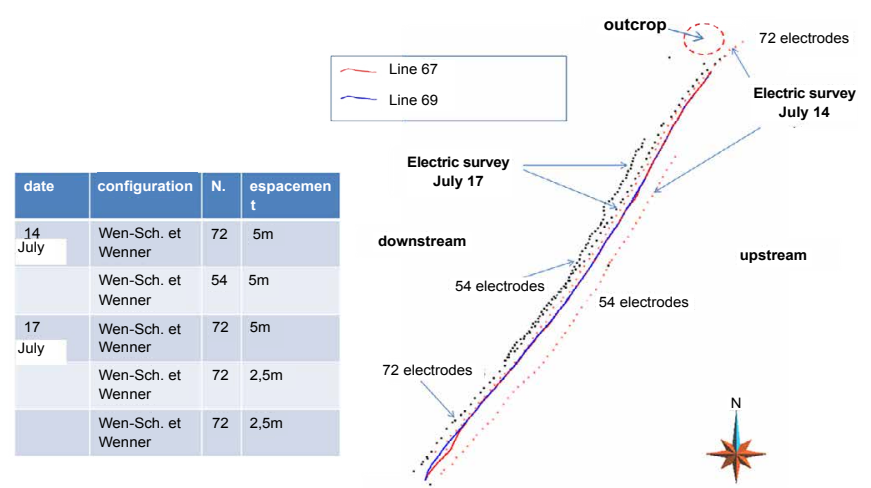

Figure 9: Location of resistivity profiles and their configurations.

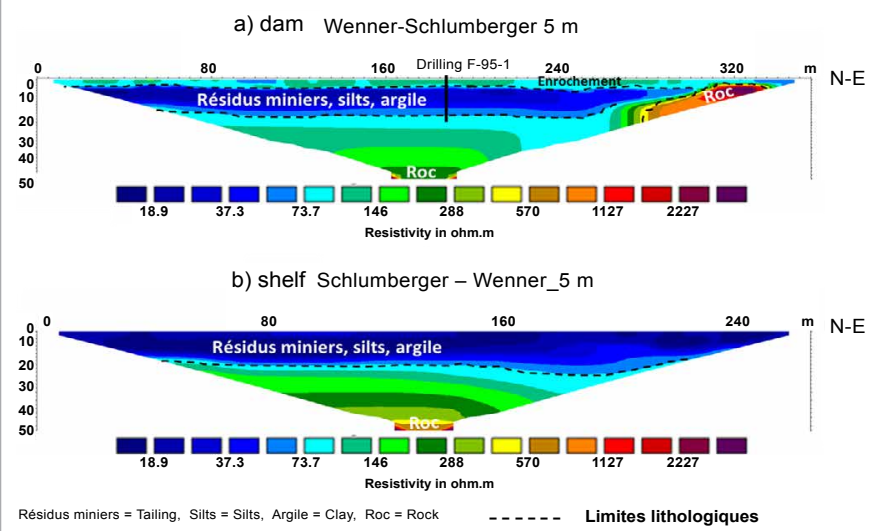

Figure 10: RES2DINV inversion results: a) survey realized in the middle of the dam, b) profile achieved on the shelf (upstream side).

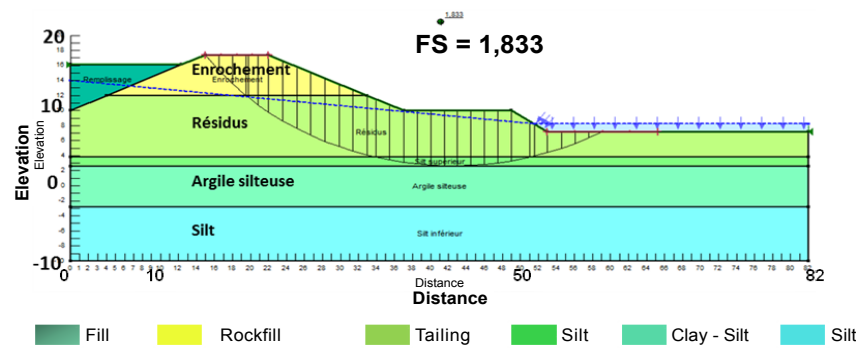

Figure 11: Geometry of the Northwest dam

\begin{tabular}{|c|c|c|}
\hline & Geotechnical driling F-95-1 & Electric resistivity \\
\hline Rockfill & $0-5 \mathrm{~m}$ & $73-300 \Omega \cdot m(0-5 \mathrm{~m})$ \\
\hline Tailings & $5-14 \mathrm{~m}$ & \multirow{2}{*}{$18-73 \Omega \cdot m(5-27 \mathrm{~m})$} \\
\hline Silty clay & $14-20 \mathrm{~m}$ & \\
\hline Silt & $20-27 \mathrm{~m}$ & \multirow{2}{*}{$73-500 \Omega \cdot m(27-50 \mathrm{~m})$} \\
\hline Morain layer & $>27(?)$ & $>570 \Omega \cdot m(>65 \mathrm{~m} ?)$ \\
\hline Bedrock & $?$ & \\
\hline
\end{tabular}

Table 2: Comparison the stratigraphic profile of geotechnical drilling and lithology estimated with the resistivity interpretation. 
shown by Maqsud et al. [64], where low resistivity values are coincide with high values of measured water content. Based on the amended soil and rock resistivity values from Palacky [65] the internal structure of the dam is interpreted as follow:

- The rockfill at the surface is highly heterogeneous in grain size also in water content. Probably this explains the large range of the resistivity variations from $73 \Omega$.m up to $300 \Omega$.m. The thickness of this layer is less than $5 \mathrm{~m}$.

- As the shelf is covered by tailings that are comprised of very fine particles and water-saturated, the inversion result shows this top layer a low resistivity less than $73.5 \Omega \mathrm{m}$. The comparison between this inversion result with that in the middle of the dam, the low resistivity ( $<100 \Omega . \mathrm{m}$ ) layer between $5 \mathrm{~m}$ to 25 $\mathrm{m}$ is interpreted as the tailings and silty clay layer (Figure 12).

- Since the geotechnical drilling stopped at $27.5 \mathrm{~m}$, from an outcrop next to the Northeast end of the dam we guess that the bedrock may have the same composition as the outcrop. The resistivity of the outcrop is more than $500 \Omega$.m, the bedrock could be at more than $50 \mathrm{~m}$ of the depth (Figure 13). Therefore, the moraine between the tailings/silty clay layer and bedrock is about $20 \mathrm{~m}$ in the thickness.

\section{Numerical Analysis on the Dam Stability}

In general, the main objectives associated with the stability analysis of a dam are to: 1) determine the conditions of the rock mass or soil slope stability; 2) to study potential failure mechanisms; 3) determine the sensitivity of slopes to different rupture trigger mechanisms; 4) test and compare the different support options and stabilization; 5) design slopes optimally for security and saving cost. The purpose of our numerical modeling is to determine the safety factor, in a perspective of assess slope stability of the embankment northwest, using SEEP/W and SLOPE/W.
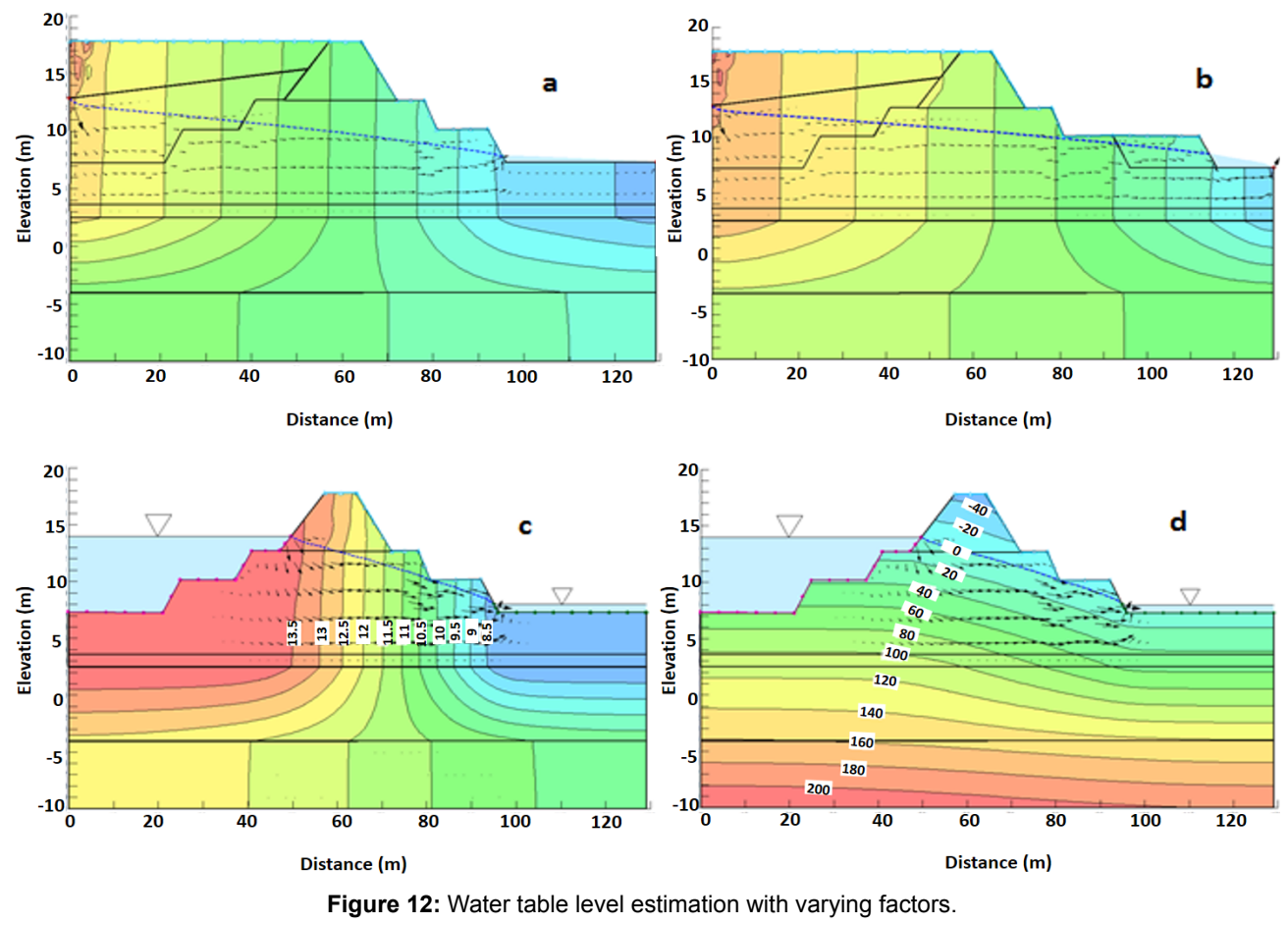

Figure 12: Water table level estimation with varying factors.

\section{The geometry of the dam}

According to the observations in issue, the slope of the Northwest dam varies between $26.6^{\circ}$ (upstream side) to $33.7^{\circ}$ (downstream side). It reaches 15 meters high. For numerical simulations, it is the geometry of the dam at the end of the construction that will be reproduced. The succession, the thickness and extent of the layers in this initial model are shown on Figure 14. The lower limit at the depth would be the very dense moraine layer overly on the bedrock. These two layers are not included in the digital model of stability analysis because they can be already considered as stable and remain in balance even after the construction of the dam.

\section{Estimation on properties of materials}

The parameter values used in SLOPE/W (Table 3) mainly come from a private geotechnical report for the mining company. The value of the specific weight of the rockfill is estimated based on previous works at similar situation. For example, the value of $19 \mathrm{kN} / \mathrm{m}^{3}$ from Massiera et al. [66] and $20 \mathrm{kN} / \mathrm{m}^{3}$ from Ormann et al. [8]. Therefore, the average value of $19.5 \mathrm{kN} / \mathrm{m}^{3}$ is used in the present study.

\section{Determination the level of the water table}

Before the simulation with SLOPE/W, we have to determine the level of groundwater that plays an important role in the safety factor. The numerical code SEEP/W has been used repeatedly to find the water level in function of variation of the height of water in the upstream lake. Following saturated hydraulic conductivity values (Table 4) collected from the publications of Chapuis and Aubertin [67], Mbonimpa et al. [68], Ormann et al. [8]. The private geotechnical report also shows a vertical hydraulic conductivity estimated in the range of $5 \times 10^{-8} \mathrm{~cm} / \mathrm{sec}$ for the silty clay and between $5 \times 10^{-3} \mathrm{~cm} / \mathrm{sec}$ to $5 \times 10^{-6} \mathrm{~cm} / \mathrm{sec}$ for silts.

We estimated the volumetric water content to 0.5 for each of the materials, since we know that the dam is not entirely saturated (above the water table). 

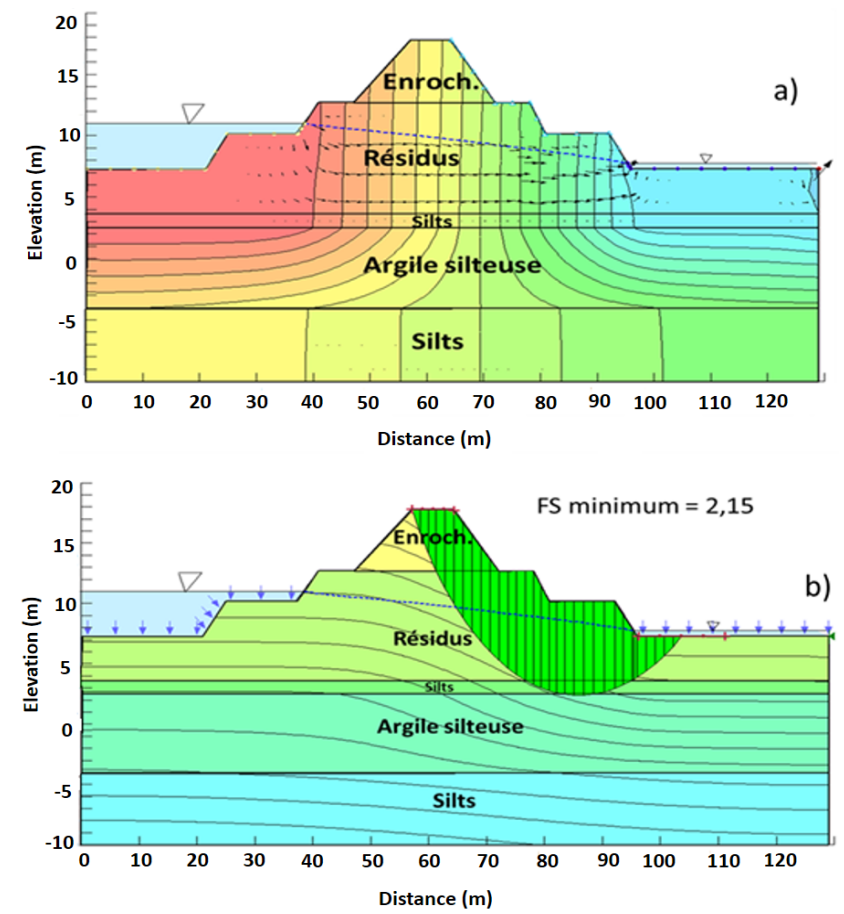

Figure 13: Image illustration of stability analysis: a) determination of the water level in the dam with SEEP/W, vertical-sub-vertical lines indicate isovalues of hydraulic load curves, b) determination of the factor security with SLOPE/W based on the model obtained with SEEP/W.

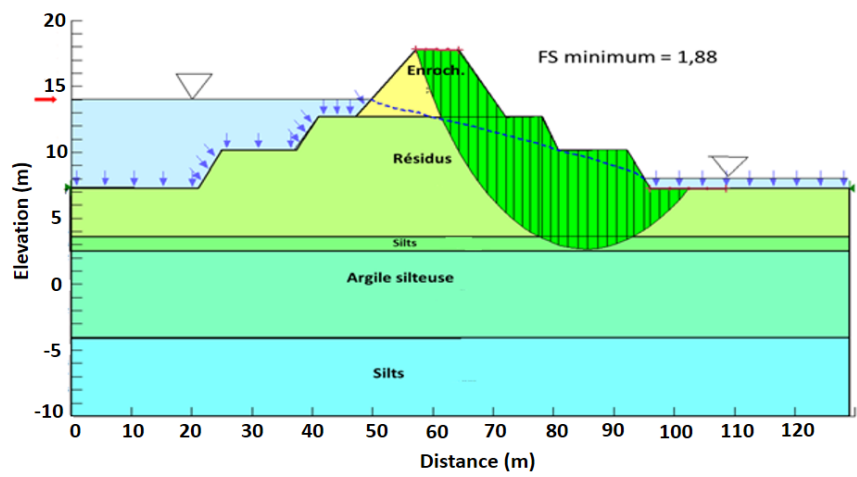

Figure 14: Stability analysis : a) water level at $11 \mathrm{~m}, \mathrm{~b}$ ) water level at $12.9 \mathrm{~m}$ c) water level at $14 \mathrm{~m}$ above zero elevation.

\begin{tabular}{|c|c|c|c|c|}
\hline Soil type & $\begin{array}{c}\text { Weight (kN } \\
\mathbf{I ~}^{\mathbf{3}} \mathbf{)}\end{array}$ & $\begin{array}{c}\text { Friction angle } \\
\text { (degrees) }\end{array}$ & $\begin{array}{c}\text { Cohésion } \\
\mathbf{( k P a )}\end{array}$ & $\begin{array}{c}\text { Undrained shear } \\
\text { strength } \mathbf{( k P a )}\end{array}$ \\
\hline Tailings & 19,0 & 35 & 0 & 0 \\
\hline Silt & 19,2 & 28 & 0 & 0 \\
\hline Silty clays & 16,5 & 30 & 0 & 40 \\
\hline Rockfill & 19,5 & 38 & 0 & 38 \\
\hline Sterile & 18,1 & 38 & 0 & 0 \\
\hline
\end{tabular}

Table 3: Parameters values used in modeling (SLOPE/W).

\section{Stability analysis with SLOPE/W}

By convention, the design the geometry of dams would ensure a minimum safety factor of 1.4 to 1.5 for each phase of construction. The minimum safety factor of 1.5 was also used in the dam stability analysis in Sweden by Ormann et al. [8] and the same value is recommended by the ACB for the long-term analysis (Table 3 ). We notice that values of the safety factor prescribed in the "Guide and how to prepare for restoration of mining sites in Quebec" by the Ministry of Energy and Natural Resources of Q u ébec (1997), are also between 1.3 and 1.5. Therefore, we use the same geometry as the initial model for varying the level of water in the upstream lake while filling it with sterile in the simulation.

The boundary conditions are set to zero pressure at the downstream end of the dam in SEEP/W. An average value of $2.10^{-8} \mathrm{~m} / \mathrm{sec}$ is used for potential infiltration in the dam. This value was estimated from the rainfall data of Mont-Brun station (Rouyn-Noranda) according to the Institut de la Statistique du Québec. Figure 15 illustrates: a) the water table level only due to the precipitation, without rockfill layer in the downstream lake; b) the water table level only due to the precipitation, there is a rockfill layer in the downstream lake; c) iso-values of hydraulic load in relation to the water table; $d$ ) iso-interstitial pressure values.

Once basic parameters are being set up, using MorgensternPrice analysis method and Mohr-Coulomb failure criterion; defining the specific gravity for each material, the effective cohesion, and the effective angle of internal friction, then we start the analysis process and end with the calculation of a minimum safety factor.

Influence of the water level on the upstream side of the dam: Figure 16 show that when the water level rises in the upstream lake, the minimum safety factor decreases. There is no storage of materials and also considering that the depth of water in the downstream lake is fixed.

When the water level (upstream side) is $11 \mathrm{~m}$ to zero elevation the safety factor is 2.15 . When the water level reaches almost $13 \mathrm{~m}$, the safety factor decreases to 2 while at $14 \mathrm{~m}$ of water level the safety factor is only 1.88 .

Effect of filling the upstream lake of the dam: In a more realistic case where the tailings in the upstream lake form a slightly inclined layer, the safety factor increases compared to the case where the lake contains only water. When more fills in the upstream lake with waste

\begin{tabular}{|c|c|c|c|c|c|}
\hline & Parameter & Rockfill & Tailings & Silt & Silty clays \\
\hline \multirow{2}{*}{ Ormann et al. [8] } & $\mathrm{Kx}(\mathrm{cm} / \mathrm{sec})$ & $10^{-3}$ & $10^{-8}$ & - & $10^{-9}$ \\
\cline { 2 - 6 } & $\mathrm{Ky}(\mathrm{cm} / \mathrm{sec})$ & $10^{-3}$ & $10^{-9}$ & - & $10^{-9}$ \\
\hline \multirow{2}{*}{ Tanriseven [7] } & $\mathrm{Kx}(\mathrm{cm} / \mathrm{sec})$ & $10^{-6}$ & $10^{-6-10^{-7}}$ & $10^{-7}$ & $10^{-9}$ \\
\cline { 2 - 6 } & $\mathrm{Ky}(\mathrm{cm} / \mathrm{sec})$ & $10^{-6}$ & $10^{-7-1} 10^{-8}$ & $10^{-8}$ & $10^{-9}$ \\
\hline Mamert et al. (2002) & $\mathrm{K}(\mathrm{cm} / \mathrm{sec})$ & & & $10^{-8}$ & $10^{-6-10^{-11}}$ \\
\hline Chapuis [30] & $\mathrm{K}(\mathrm{cm} / \mathrm{sec})$ & - & - & $10^{-8}$ & $10^{-9}$ \\
\hline Values used in SEEP/W & $\mathrm{Kx}=\mathrm{Ky}(\mathrm{cm} / \mathrm{sec})$ & $10^{-6}$ & $10^{-7}$ & $10^{-8}$ & $10^{-9}$ \\
\hline
\end{tabular}

Table 4: Reference of saturated hydraulic conductivity values $\left(\mathrm{k}_{\text {sat }}\right)$.

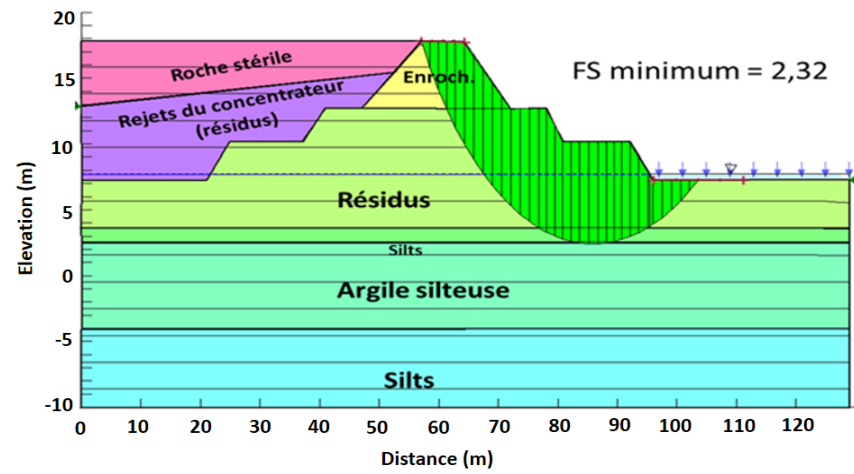

Figure 15: Stability analysis: a) upstream lake filled partially with tailings, b) filling with waste rock over the tailings layer, c) water level in the downstream lake at $8 \mathrm{~m}$. 


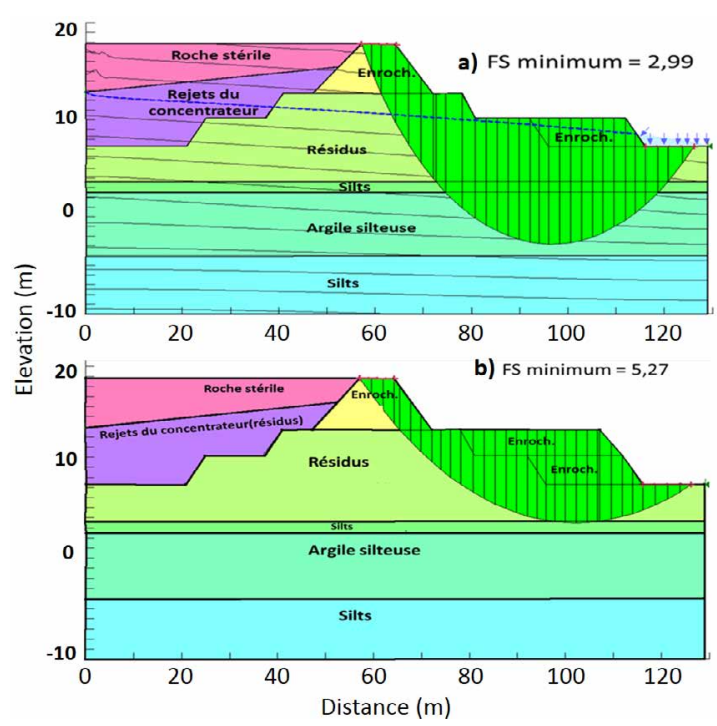

Figure 16: Stability analysis: a) add a rockfill layer in the downstream lake, b) another layer of waste rocks overlaid on the previous one.

rock, assuming there is only water infiltration from rainfall, the safety factor goes from 1.75 to 2.16 . If the water level in the downstream lake rises to $8 \mathrm{~m}$ and then in stationary regime, there is an even higher safety factor of 2.32 for the dam.

By filling part of the downstream lake with waste rock and the infiltration conditions of potential water either side of the dam, the safety factor is 2.99. Adding another layer of waste rock over the existing one in downstream side and under the same conditions where there is only the infiltration of water from rainfall on either side of the dam, the safety factor increases significantly to 5.27 as that is expected $[69,70]$.

\section{Conclusion}

The two geophysical $t$ echniques have identified the internal structure of the dam which is consistent with the observed lithology in geotechnical drilling F-95-1.

The method of electrical resistivity demonstrates some heterogeneity of materials of the dam, particularly in the upper layer of riprap by a strong variation of resistivity, probably caused by the variation in particle size of $\mathrm{m}$ aterials. This heterogeneity could potentially cause differential settlement of the dam in time. The saturated zone in water as the layer of $t$ a ilings is characterized by low electrical resistivity values $(<100 \Omega \cdot m)$. This study demonstrates the great potential of geophysical methods for monitoring for embankments.

By combin ing the study of the internal structure and stability analyzes, the results will be useful not only for the present condition assessment of the dam; thus they can be considered when planning new developments of the mine.

An analysis of deformation and effective stress would be useful in future work. If the effective stress decreases, the shear strength of the material decreases and this may generate rupture. Wherever, possible, it would be necessary to carry out geotechnical drilling to collect samples in order to deter mine real geomechanical parameters, untimely to perform numerical simulations of more updated stability analysis.

\section{References}

1. Simeon A, Lapointe U (2015) Mount polley mine disaster's first anniversary no reason to celebrate.
2. Kiernan $P$ (2015) Engineers say Brazilian disaster shows world-wide danger from Hoover Dam-size earthen structures holding 'tailings' waste.

3. Rico M, Benito G, Salgueiro AR, Díez-Herrero A, Pereira HG (2007) Reported tailings dam failures: $A$ review of the European incidents in the worldwide context. J Hazard Mater 152: 846-852.

4. Mbonimpa M (2014) Mining Geotechnical. Notes. University of Quebec in Abitibi Temiscamingue, (UQAT).

5. Azam S, Li Q (2010) Tailings Dam Failures: A Review of the Last One Hundred Years. Geotechnical News, December 2010.

6. Engels J, Schönhardt M, Witt KJ, Benkovics I, Berta Z, et al. (2004) Tailings management facilities - Intervention actions for risk reduction: A European research and technological development project. P 52.

7. Zardari MA (2010) Stability of tailings dams. Luleå University of technology. SE-97187 Luleå, Sweden.

8. Ormann L, Zardari MA, Mattsson H, Bjelkevik A, Knutsson S (2013) Numerical analysis of strengthening by rockfill embankments on an upstream tailings dam. Canadian Geotech J 50: 391-399.

9. Zardari MA, Ormann L, Mattsson H, Knutsson S (2014) Numerical analysis of staged construction of an upstream tailings dam 150-160.

10. Mériaux $P$, Royet $P$, Folton $C$ (2001) Surveillance, maintenance and diagnosis of flood protection dykes: a practical guide for owners and managers. Monitoring maintenance and diagnosis of flood protection dikes: practical guide for owners and managers. Cemagref Editions. 191 p.

11. Lepetit $L$ (2002) Study of a diagnostic method of dikes taking into account the risk of liquefaction. Doctoral thesis, Université Blaise Pascal-Clermont 2: 207.

12. Serre D (2005) Evaluation of the performance of flood protection dams Modeling of decision criteria in a geographic information system. Doctoral thesis, University of Marne-La-Vallée.

13. Adrian N (2004) Ground-penetrating radar and its use in sedimentology: Principles, problems and progress. Earth-Sci Rev 66: 261-330.

14. Di Prinzio M, Bittelli M, Castellarin A, Pisa PR (2010) Application of GPR to the monitoring of river embankments. J Appl Geophy 71: 53-61.

15. Plati C, Loizos A (2013) Estimation of in-situ density and moisture conten in HMA pavements based on GPR trace reflection amplitude using different frequencies. J Appl Geophy 97: 3-10.

16. Chlaib HK, Mahdi H, Al-Shukri H, Su MM, Catakli A, et al. (2014) Using ground penetrating radar in levee assessment to detect small scale animal burrows. J Appl Geophy 103: 121-131.

17. Halabe Udaya B, Master K, Kausel E (1989) Propagation characteristics of electromagnetic waves in concrete. Technical report 106.

18. Halabe UB, Maser KR, Kausel EA (1993) Condition assessment of reinforced concrete structures using electromagnetic waves. ACI Mater J 92: 511-523.

19. Halabe UB, Chenn H, Bhandarkar V, Sami Z (1997) Detection of sub-surface anomalies in concrete bridge decks using ground penetrating radar. $\mathrm{ACl}$ Mate J 94: 396-408.

20. Morey RM (1998) Ground penetrating radar for evaluating subsurface conditions for transportation facilities. National academy press, Washington, D.C

21. Huston D, Hu JQ, Maser K, Weedon W, Adam C (2000) GIMA ground penetrating radar system for monitoring concrete bridge decks. J Appl Geophy 43: 139-146.

22. Hubbard SS, Zhang J, Monteiro PJM, Peterson JE, Rubin Y (2003) Experimental detection of reinforcing bar corrosion using nondestructive geophysical techniques. ACI Mater J 100: 501.

23. Barnes CL, Trottier JF (2004) Effectiveness of ground penetrating radar in predicting deck repair quantities. J Infrastruct Syst 10: 69-76.

24. Loizos A, Plati C (2006) Accuracy of pavement thicknesses estimation using different ground penetrating radar analysis approaches. NDT \& E international 40: 147-157.

25. Sbartaï ZM, Laurens S, Rhazi J, Balayssac JP, Arliguie G (2007) Using radar direct wave for concrete condition assessment: correlation with electrical resistivity. J Appl Geophy 62: 361-374.

26. Rhazi J, Dous O, Laurens S (2007) A new application of the GPR technique 
to reinforced concrete bridge decks. Proceedings of the 4th Middle East NDT Conference and Exhibition, Kingdom of Bahrain.

27. Alani AM, Aboutalebi M, Kilic G (2013) Applications of ground penetrating radar (GPR) in bridge deck monitoring and assessment. J Applied Geophysi 97: 4554.

28. Benedetto A (2013) A three dimensional approach for tracking cracks in bridges using GPR. J Applied Geophysi 97: 37-44

29. Krysiński L, Sudyka J (2013) GPR abilities in investigation of the pavement transversal cracks. J Applied Geophysi 97: 27-36.

30. Chapuis RP (1999) Guide to pumping tests and their interpretations. Government of Quebec-Publications of Québec 156.

31. Garambois S, Sénéchal P, Perroud H (2002) On the use of combined geophysics to assess water content and water conductivity of near surface formations. J Hydrol 259: 32-48.

32. Kazakis N, Vargemezis G, Voudouris KS (2016) Estimation of hydraulic parameters in a complex porous aquifer system using geoelectrical methods. Sci Total Environ 550: 742-750.

33. David JM (2008) Geophysical survey in archaeological field evaluation. In Jones DM (Ed.). English Heritage Publishing 61.

34. Conyers Lawrence B (2013) Interpreting ground-penetrating radar for archaeology. Left Coast Press, Walnut Creek, California.

35. Eva N, Karous M, Zajicek A, Kayousova M (2013) Evaluation of ground penetrating radar and vertical electrical sounding methods to determine soil horizons and bedrock at the Locality Dehtare. Soil and Water Res 8: 105-112.

36. Gordon MO, Broughton K, Hardy MSA (1998) The assessment of the value of GPR imaging of flexible pavements. NDT \& E International 31: 429-438.

37. Denahan BJ, Smith DL (1984) Electrical resistivity investigation of potential cavities underlying a proposed ash disposal area. Environ Geo Water Sci 6 : $45-49$

38. Maillol JM, Seguin MK, Gupta OP, Akhauri HM, Sen N (1999) Electrical resistivity tomography survey for delineating uncharted mine galleries in West Bengal, India. Geophys Prospect 47: 103-116.

39. Ernstson K, Kirsch R (2006) Geoelectrical methods. Groundwater Geophys 85-117.

40. Pánek T, Margielewski W, Táborik P, Urban J, Hradecký J, et al. (2010) Gravitationally induced caves and other discontinuities detected by 2D electrical resistivity tomography: case studies from the Polish Flysch Carpathians. Geomorphology 123: 165-180.

41. Martínez-Pagán PD, Gómez-Ortiz T, Martín-Crespo JI, Rosique M (2013) The electrical resistivity tomography method in the detection of shallow mining cavities. A case study on the Victoria Cave, Cartagena (SE Spain). Engineering Geology 156: 1-10.

42. Knight RJ, Enders AL (2005) An introduction to rock physics principles for near-surface geophysics. Near-surface geophysics. Society of exploration geophysicists. Tulsa, Oklahoma.

43. Saleem M, Shameemt M, Hussain SE, Maslehuddin M (1996) Effect of moisture, chloride and sulphate contamination on the electrical resistivity Portland cement concrete. Constr Build Mater 10: 209-214

44. Slater $L$ (2007) Near surface electrical characterization of hydraulic conductivity: from petrophysical properties to aquifer geometries-A review. Surv Geophys 28: 169-197.

45. Aina A, Olorunfemi MO, Ojo JS (1996) An integration of aeromagnetic and electrical resistivity methods in dam site investigation. Geophys 61: 349-356.

46. Johansson S (1997) Seepage monitoring in embankment dams. Ph.D. thesis, Royal institute of technology de Stockholm, Sweden.

47. Panthulu TV, Krishnaiah C, Shirke JM (2001) Detection of seepage paths in earth dams using self-potential and electrical resistivity methods. Engi Geol 59: 281-295.

48. Jackson PD, Northmore KJ, Meldrum PI, Gunn DA, Hallam JR, et al. (2002) Non-invasive moisture monitoring within an earth embankment - a precursor to failure. NDT \& E International 35: 107-115.

49. Fauchard C, Mériaux P (2004) Geophysical and geotechnical methods for the diagnosis of flood protection dykes. Cemagref publications.
50. Hennig T, Weller A, Canh T (2005) The effect of dike geometry on different resistivity configurations. J Applied Geophysi 57: 278-292.

51. Mainali G (2006) Monitoring of tailings dams with geophysical methods. Lulea University of Technology, Sweden.

52. Cho IK, Yeom JY (2007) Crossline resistivity tomography for the delineation of anomalous seepage pathways in an embankment dam. Geophysics 72 G31-G38.

53. Fargier $Y$ (2011) Development of electrical resistivity imaging for the recognition and monitoring of hydraulic structures in earth. Doctoral thesis, sciences for engineers geoscience architecture, École Centrale de Nantes.

54. Sjödahl P (2006) Resistivity investigation and monitoring for detection of internal erosion and anomalous seepage in embankment dams. Ph.D. thesis, Lund University, Sweden.

55. Sjödahl P, Dahlin T, Zhou B (2006) 2.5D resistivity modeling of embankment dams to assess influence from geometry and material properties. Geophysics 71: G107-G114.

56. Sjödahl P, Dahlin T, Johansson S, Loke MH (2008) Resistivity monitoring for leakage and internal erosion detection at Hällby embankment dam. J Applied Geophysi 65: 155-164.

57. Kuras O, Pritchard JD, Meldrum PI, Chambers JE, Wilkinson PB, et al. (2009) Monitoring hydraulic processes with automated time-lapse electrical resistivity tomography. Comptes rendus geoscience 341: 868-885.

58. Daniels JJ, Dyck AV (1984) Borehole resistivity and electromagnetic methods applied to mineral exploration. 22: 80-87.

59. Douglas WO, Yaoguo L, Colin G, Peter K, Theo A, et al. (1998) Applications of geophysical inversions in mineral exploration. The Leading Edge 17.

60. López W, González JA (1993) Influence of the degree of pore saturation on the resistivity of concrete and the corrosion rate of steel reinforcement. Cement and Concrete Res 23: 368-376.

61. Patriarca C, Tosti F, Velds C, Benedetto A, Lambot S, et al. (2013) Frequency dependent electric properties of homogeneous multi-phase lossy media in the ground-penetrating radar frequency range. J Applied Geophysi Volume 97: 81 88.

62. Saad B, Mitri H (2011) Hydromechanical analysis of upstream tailings disposa facilities. J Geotech Geoenviron Engi 137: 27-42.

63. Boussicault B (2007) Geophysical study of a water retention dam, solbec tailings park, stratford, Quebec. Master's thesis in Earth Sciences. University of Quebec, INRS Eau Terre et Environnement.

64. Maqsoud A, Bussière B, Aubertin M, Chouteau M, Mbonimpa M (2011) Field investigation of a suction break designed to control oxygen barrier slopeinduced desaturation. Canadian Geotech J 48: 53-71.

65. Palacky GJ (1987) Resistivity characteristics of geologic targets. Soci Exp Geophys 53-129.

66. Massiéra M, Vautour J, Coulibaly Y, Hammamji Y, Szostak-Chrzanowski A (2006) Behavior of rockfill dams with an upstream mask of cement concrete based on granular alluvium. The 2006 Annual General Conference of the Canadian Society for Civil Engineering. Galgary, Alberta, Canada.

67. Chapuis RP, Aubertin M (2001) A simplified method to estimate saturated and unsaturated seepage through dikes under steady state conditions. Can Geotech J 38: 1321-1328.

68. Mbonimpa M, Aubertin M, Chapuis RP, Bussière B (2002) Practical pedotransfe functions for estimating the saturated hydraulic conductivity. Geotech Geol Engi 20: 235-259.

69. Tanriseven EN (2012) Stability investigation of ETI copper mine tailings dam using finite element analysis. Master thesis at Middle East Technical University.

70. Quebec Institute of Statistics (2014) Ministry of sustainable development, environment, wildlife and parks, climate normals. 1981-2010. 